\title{
LA FOTOGRAFIA PER A L'APRENENTATGE DE LA HISTÒRIA
}

\author{
Antoni Gavaldà Torrents i Antoni Santisteban Fernández. Àrea de Didàctica de les Ciències Socials. URV
}

\section{El patrimoni fotogràfic}

El concepte patrimoni és un terme que comprèn infinitat d'elements que identifiquen una comunitat i que donen testimoni de la seva existència cultural. El patrimoni històric se centrarà en el conjunt d'objectes de la cultura material, fonts d'informació escrita o iconogràfica, així com qualsevol tipus de testimoni en format auditiu o visual. Dins del patrimoni històric caldrà considerar la vessant escrita i la iconogràfica.

Aquest darrer patrimoni ha merescut una atenció relativa per part de les institucions en els darrers anys. Els arxius han millorat instal-lacions, han catalogat $i$ incorporat noves fonts. En aquests canvis cal destacar la creació de serveis didàctics, que han apropat l'alumnat de l'ensenyament obligatori a les fonts de la història. En general, l'aspecte més descuidat, ha estat, però, la recopilació del patrimoni iconogràfic, ja que encara hi ha arxius, museus, biblioteques i altres institucions culturals on aquest apartat està per resoldre. El patrimoni fotogràfic, per tant, amb les excepcions de rigor que indubtablement existeixen, no ha comptat amb tractaments arxivístics d'acord amb el valor de les seves fonts. Això ha succeït d'aquesta manera perquè els professionals encarregats dels arxius, igual que els historiadors que els fan servir, han estat més sensibles davant d'un document escrit que davant d'una informació gràfica.

El patrimoni fotogràfic va adquirir consciència en debats $i$ trobades a finals dels anys 80 i durant els 90 del segle passat, al mateix temps que apareixien les històries gràfiques en alguns municipis. Les primeres històries gràfiques, desiguals quant a resultats, van aportar una forma de contrast de la història entre el passat i el present que, quan s'acompanyaren de textos explicatius, van ajudar a relativitzar la realitat $i$ a entendre la perspectiva de la història més propera. Una altra aportació que proporcionaren va ser la humanització de la història, ja que l'observador es podia sentir més prop de la història, o fins i tot formar-ne part.

El problema dels fons fotogràfics ha estat la dispersió, la planificació tardana dels organismes competents i el cost elevat del procés de conservació. A Catalunya, un monogràfic de la revista Plecs d'Història Local de l'Avenç de l'octubre del 1989, amb el títol Els Arxius: la normalit- zació pendent, informava dels resultats de les II Jornades d'Arxivística de Catalunya, constatant que el patrimoni documental, tot i els avenços dels darrers anys, era el darrer esglaó de la cultura. Un article de Vicente (1989) sobre els arxius d'imatges analitzava la situació del moment. Hi deia que als arxius històrics de caràcter públic existeixen fons gràfics, organitzats de formes diverses; que als arxius locals i comarcals es troben fons importants, en alguns casos sense cap tractament arxivístic o realitzat de forma superficial; que als museus es donaven tres variants: les fotografies de les peces del mateix museu; les fotografies en format de fons museístic com qualsevol altre element del museu, i en un tercer cas, com a col-lecció local i comarcal; que en les biblioteques populars, amb freqüència estaven sense catalogar; que en fons d'institucions i empreses públiques existia un material ric; i que també es localitzaven fons gràfics als arxius privats i en medis de premsa.

Les Jornades Antoni Varés. La imatge i la recerca històrica, celebrades a Girona en els anys 90 , han estat un referent important en el treball d'historiadors i professionals dels arxius, així com de professorat interessat en aquest tipus de font històrica per a l'ensenyament.

\section{La fotografia i les Ciències Socials. Unes fonts poc utilitzades}

S'ha escrit que una imatge val més que mil paraules, i estem d'acord amb l'afirmació en la seva concepció, però és evident que l'aportació a la història depèn de l'ús que en fem. Una imatge val ben poc si no està localitzada en un context social determinat, si no aporta elements de semblança i de contrast amb altres imatges, si no dilucida sobre la finalitat que es pretenia al realitzarla. De fet hi ha fotografies -igual que documents- que resulten parcials, summament ambigües, tant per la forma de presentació com pel contingut que duen implícit.

Podríem comentar, tot i que no és la intenció del treball, la imatge absent o la imatge ignorada, important per a la investigació històrica i molt d'actualitat en alguns dels actuals mitjans d'informació, intervinguts pel poder polític o econòmic. Les imatges que mostren la realitat són substituïdes per d'altres que ensenyen un altre món, millor o pitjor, segons la intencionalitat de la infor- 


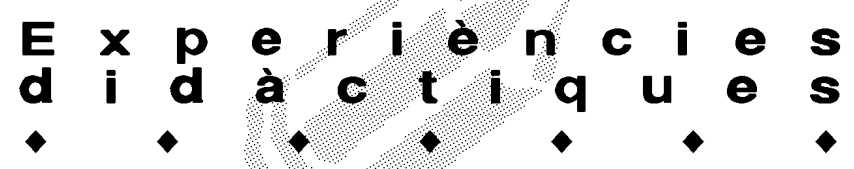

mació. En aquest cas la lectura de la imatge no és només una interpretació del que observem, sinó que també requereix una indagació d'allò que no apareix, o fins i tot, valorar allò que se'ns amaga (ELORZA, 2000).

L'ús de la imatge com a document històric ha estat analitzat per alguns autors des de la comprensió de les possibilitats que atresoren. Gaskell (1994) i Burke (2001) hi han incidit. El primer ho ha analitzat des dels interessos que regeixen el pensament i la pràctica dels que manegen material visual. El segon, des d'una perspectiva en la qual les imatges no són considerades reflexos objectius d'un espai i d'un temps, sinó que formen part del context social que les va produir. Gaskell aprofundeix la reflexió en la "història de les imatges" assenyalant que la fotografia ha generat un impacte cultural en els darrers cent cinquanta anys, d'igual forma que les imatges visuals en moviment registrades en els vídeos i altres mitjans la generen actualment. Burke ha ampliat el camp d'acció al visualitzar les fonts, assenyalant que els historiadors no haurien de limitar-se a utilitzar les imatges només com a testimonis, sinó com a elements d'impacte en la imaginació històrica, en el sentit de permetre imaginar el passat d'una manera més viva. Amb tot, remarca l'enorme fragilitat en l'ús del testimoni de les imatges, ja que, d'igual forma que les fonts escrites, haurien de passar pel sedàs de la crítica, per tal com poden plantejar problemes de context, de funció, de retòrica, de qualitat del record si es tracta d'un testimoni, etc., significant que la utilitat hauria d'estar relacionada amb les preguntes que pogués suportar.

Per tot aquest entramat és necessari entendre la iconografia de la imatge, la interpretació a través dels seus elements i dels detalls. Burke proposa dues alternatives de confluència. Una, seguiria les tres pautes extretes d'Erwin Panofsky, segons les quals es permetria assumir l'apreciació de la fotografia en la seva totalitat $i$ se sabria quan aquesta fotografia té rang històric o no.

El primer estadi seria la descripció de la imatge i consistiria a identificar els objectes (arbres, edificis, animals, personatges, etc.), i situacions (festes, batalles, processons, etc.).

El segon seria l'anàlisi iconogràfica relacionada amb el significat convencional (reconèixer que un determinat autobús era l'autobús que feia el trajecte entre Tarragona i Barcelona, o que una menjada al camp era un acte d'afirmació carlina).

El tercer estadi correspondria al nivell iconològic, o sigui el significat intrínsec o "els principis subjacents que revelen el caràcter bàsic d'una nació, una època, una classe social, una creença religiosa o filosòfica".

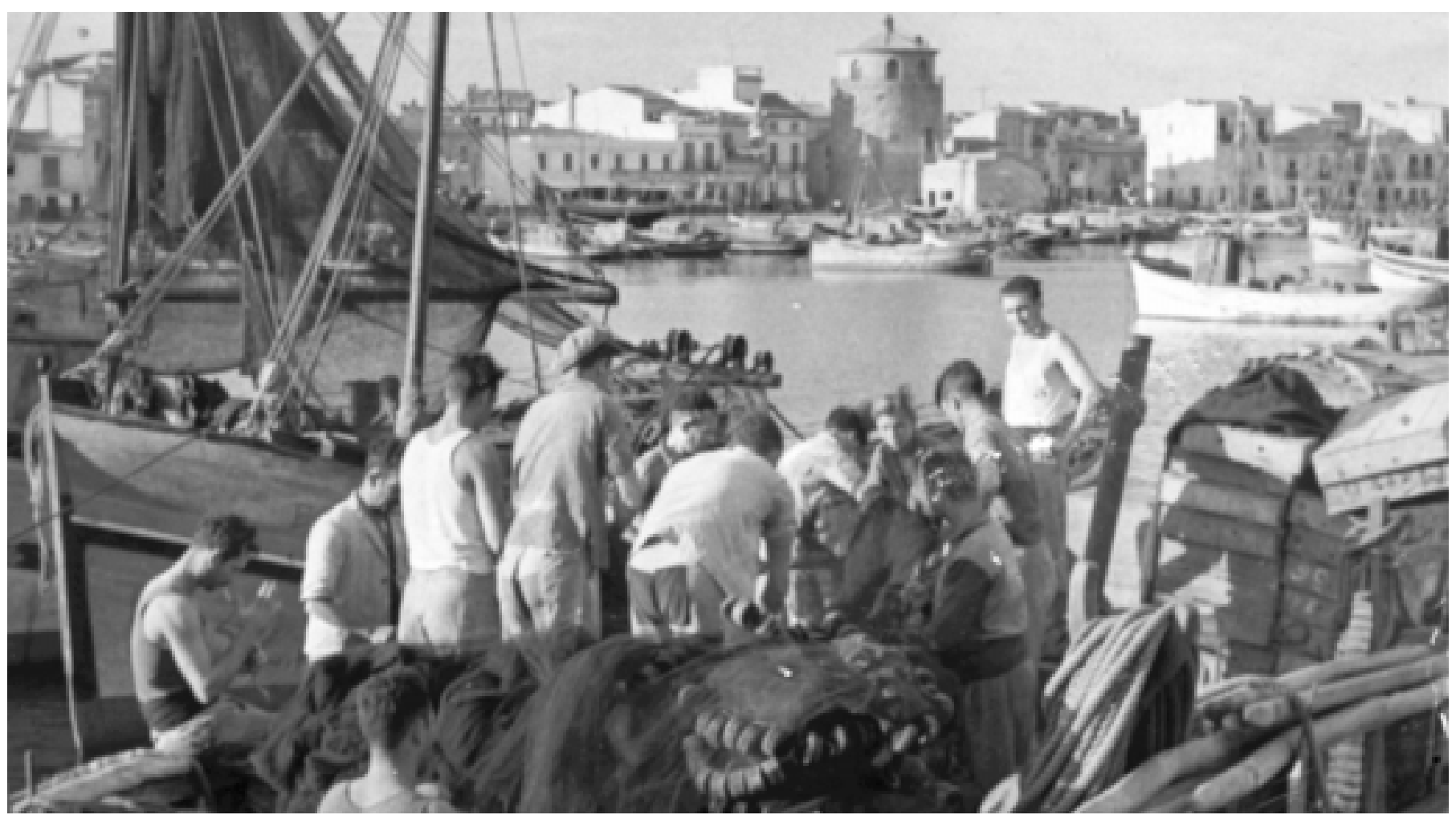

Fotografia realitzada per Francisco Ferré, sobre l'any 1944 a Cambrils, que ens permet treballar les activitats econòmiques (Miriam Comes. $2 \mathrm{n}$ de LE) 


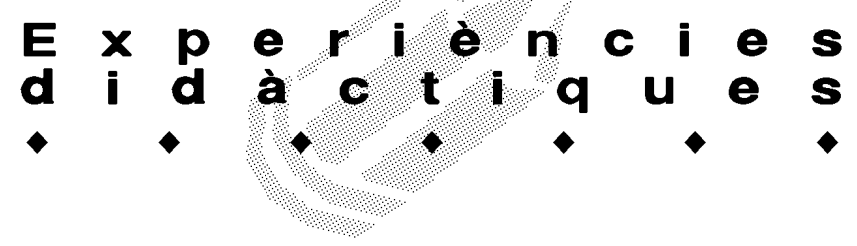

La segona alternativa proposada seria acceptar que "les imatges no són un reflex d'una determinada realitat social, ni un sistema de signes mancats de relació amb la realitat social, sinó que ocupen múltiples posicions intermèdies entre ambdós extrems", donant a entendre que la lectura de la imatge històrica requereix d'una anàlisi de diversos factors, cosa que reflecteix la complexitat de la construcció de la història. En un treball anterior, Riego (1994) refermava que cada fotografia històrica és com un mapa de significats i que la seva anàlisi requereix, a més de la descripció, la interpretació dels diferents elements que la componen. En una línia semblant existeixen altres treballs que consideren la fotografia com un tipus de memòria específica, com un codi de significats o un llenguatge propis de l'espai i del temps de quan aparegueren.

\section{Cap a un currículum que valori la imatge}

Les imatges d'origen fotogràfic, que van donar Iloc després al cinema $\mathrm{i}$ al vídeo, tenen un llenguatge específic, difícil d'aprendre i amb múltiples variants. La fotografia per a la publicitat és un bon exemple per comprendre com es pot manipular la realitat, però també existeixen altres exemples per demostrar la gran complexitat de la lectura de la imatge, com són la imatge periodística o la imatge amb finalitats polítiques. El format, l'angle de visió o el plànol triat per l'autor no són aspectes externs de la fotografia, sinó part de la seva intencionalitat, elements del llenguatge visual. L'enquadrament vertical, l'angle picat o un pla de detall, no són coincidències estètiques, sinó eleccions tècniques amb la finalitat de ressaltar determinats aspectes del món que se'ns mostra. Aquest món és, per definició, una veritat inventada, una realitat creada amb un llenguatge que s'ha de dominar per comprendre'l.

En l'ensenyament social la lectura d'imatges hauria de ser, pel que comentem, una finalitat de primer ordre. Un dels valors que ens poden ajudar a entendre aquesta situació és la presència i la funció de les imatges dels llibres de text. Fins fa uns anys les imatges quedaven limitades a unes fotografies o dibuixos com a il.lustracions, amb la intenció de donar una mica de color al text o, com a molt, reforçar la idea exposada per l'autor (VALLS, 1995). Aquesta situació ha millorat i, en algunes obres, les imatges comencen a jugar un paper important com a font d'informació. La nostra opinió és que les imatges, al llibre de text o com a materials curriculars, es justifiquen perquè poden aportar elements importants a l'aprenentatge conceptual (DEFORGE, 1992). Malgrat tot, encara avui dia queda molt de camí per a recórrer i, tot i que vivim en el món de la imatge, als manuals escolars l'exposició i la documentació escrites són la principal font d'activitats.

La lectura de la imatge relacionada amb l'ensenyament de les ciències socials està present en diferents disciplines: en geografia les imatges com fotografies aèries $o$ de paisatge, les imatges esquemàtiques que reprodueixen models per a l'urbanisme, etc. són d'un gran valor didàctic; en història de l'art l'ús de la imatge és imprescindible, ja que la mateixa iconografia és objecte d'estudi, i també perquè la seva aportació al llenguatge visual és fonamental. Per a la història, la imatge és una documentació bàsica per a l'ensenyament d'una part de la realitat del passat. Les imatges arriben a ser, per a determinats moments, d'una importància semblant a la que avui dia tenen els mitjans de comunicació de masses. En particular la fotografia, però també el cartell o la caricatura ens apropen a alguns aspectes de la nostra història pròxima, per reconèixer diverses maneres de viure i poder-les ensenyar, així com per poder entendre determinades actituds socials 0 polítiques (MORENO, 2000). La fotografia és un vestigi voluntari, no involuntari com una eina agrícola gastada o vella. No es un indici, sinó un senyal creat per conservar-se com a vestigi (SEGA, 1986). La fotografia respon a una necessitat social d'identitat, d'autocelebració, de conservació de la nostra imatge. En les classes populars la fotografia ha estat la substituta de la memòria oral.

Per als alumnes les fotografies familiars dels primers anys i les dels seus pares són la principal font de coneixement de la seva història personal i un instrument essencial per a la comprensió del temps històric. Posteriorment les fotografies han de ser objecte d'una anàlisi, des de la seva cronologia i el seu context, fins als valors socials implícits que representen. Hem de recordar que la imatge no requereix d'una decodificació digital com el llenguatge verbal, sinó analògica, i necessita d'una visió global i d'una avaluació del que és essencial i del que és accessori. A partir d'aquesta concepció, la imatge ens ajudarà per a la reconstrucció de conceptes, per a l'aplicació de coneixements, per a la motivació, per a l'elaboració de preguntes, per a l'avaluació del saber històric del nostre alumnat de qualsevol edat, entre d'altres possibilitats.

Considerem, per tant, que la fotografia com a font d'informació de la història és un recurs bàsic i assequible, a través del qual el nostre alumnat pot introduir-se en el llenguatge visual, al mateix temps que a profundeix en una font d'informació històrica original que li ajudarà a comprendre el procés de construcció del mosaic de la història. Tanmateix, la fotografia familiar és també un recurs per a l'ensenyament de la història, de tal manera que el professorat hauria de conèixer bé aquest material curricular per a la seva utilització a les classes. Aquest 


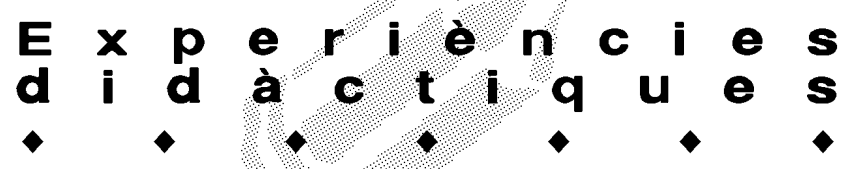

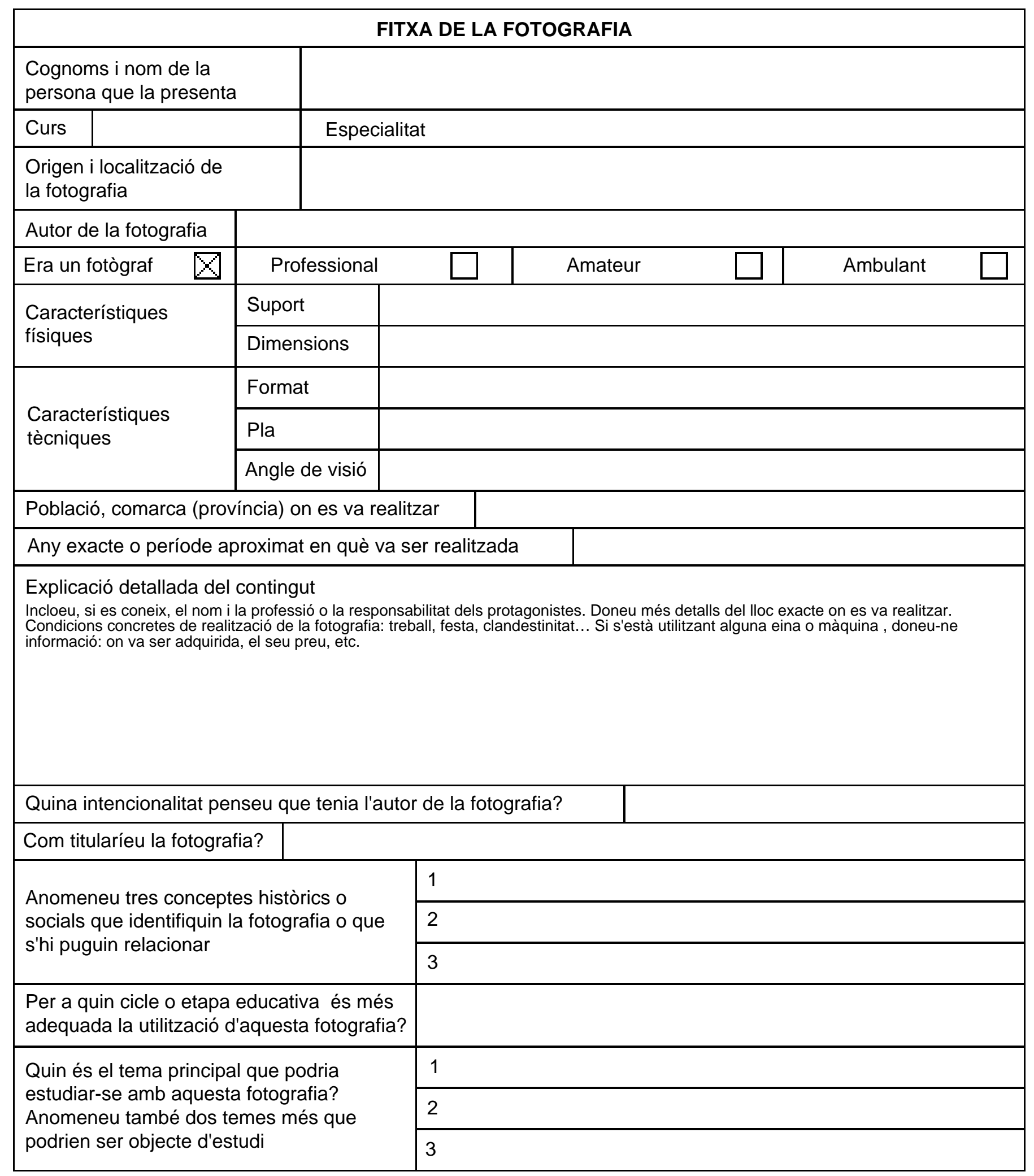




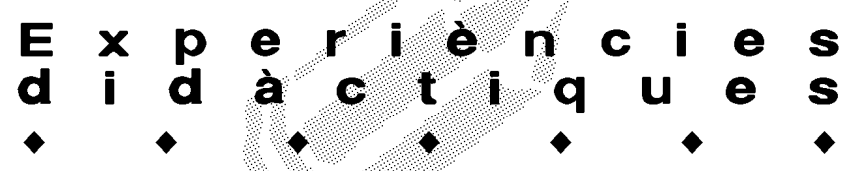

recurs és indicat, en especial, per a la comprensió del temps històric a l'escola primària (CORRIGAN, 1995).

El paper dels arxius i la seva vessant didàctica han estat motiu de debat en la celebració de les Primeres Jornades Ensenyament-Arxius, celebrades a Barcelona el 2002. Tot i que la majoria d'aportacions fan referència al document escrit, hi ha alguna proposta sobre la documentació gràfica. Navarro (2002), indica que la fotografia es pot estudiar des de diferents perspectives $i$ des de l'anàlisi del seu valor artístic, històric, testimonial, documental, informatiu, pedagògic i social, proposant fins a nou models d'experiències, que demostren el potencial i la capacitat de possibles treballs amb materials fotogràfics d'arxius. Hi explicita des de tallers -d'història de la fotografia, de crítica i d'anàlisi d'imatges-, fins a concurs de fotografies, exposicions de fotografies a l'escola o a l'institut, díptics informatius o aplicacions informàtiques interactives... En aquest àmbit és interessant l'aportació d'Arqué (2002), partidari d'introduir les fonts fotogràfiques a l'ensenyament amb la finalitat de desenvolupar en els alumnes les capacitats d'observació, d'anàlisi i d'interpretació, que els permeti discriminar entre informació i coneixement. En la seva reflexió sistematitza les funcions del document fotogràfic en el camp de la investigació social, la metodologia i els procediments per interrogar i analitzar les fonts fotogràfiques, i acaba amb un bloc d'avantatges i inconvenients del treball amb aquest tipus de fonts.

\section{Una experiència de recerca familiar}

La nostra experiència s'origina en el treball al Laboratori de Didàctica de les Ciències Socials - LDCS(GAVALDÀ i SANTISTEBAN, 2002). L'alumnat aporta cada any fotografies i documents de la seva història familiar, dels quals ells mateixos realitzen una sèrie de fitxes per arxivar el seu contingut, classificar-lo i facilitar la seva recerca posterior, i, com a últim pas del seu tractament, s'emmagatzemen a l'ordinador per mitjà d'un escàner i són tractades amb eines informàtiques. Aquesta informació passa a formar part dels recursos que es fan servir a les classes de Didàctica de les Ciències Socials, per fer referència a determinats aspectes de la història, o per a la creació de materials curriculars d'ensenyament i aprenentatge de la història. Una activitat posterior, en coordinació amb el Museu d'Història de Catalunya de Barcelona (MHC), permet treballar la vessant museística com a complement de la utilitat de la documentació històrica.

La fitxa de la fotografia recull elements diversos, agrupats en diferents aspectes interrelacionats:

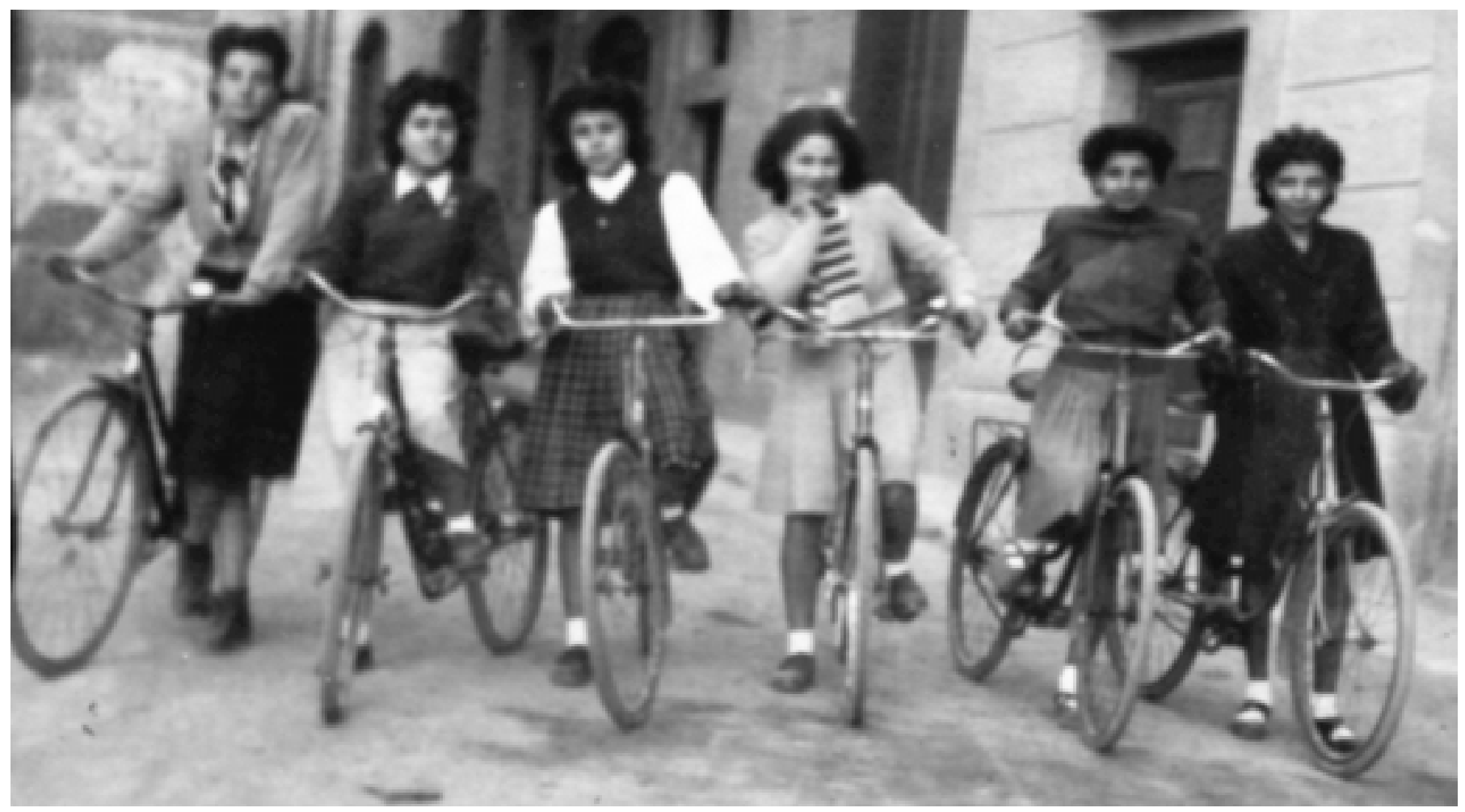

Imatge d'un fotògraf ambulant a Vila-seca sobre el 1947, a la tradicional correguda de cintes, que ens permet treballar els costums (Griselda Moreso. 2n d'EM) 


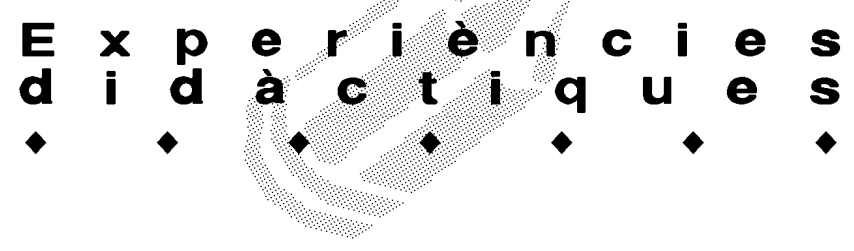

a) qüestions sobre l'origen, la localització i l'autoria de la fotografia;

b) sobre les seves característiques físiques, com el suport o les dimensions;

c) les qüestions tècniques, com el color, el format o l'enquadrament, el plànol i l'angle de visió;

d) coordenades espai i temps per situar el seu contingut;

e) descripció de l'escena, personatges i objectes que hi apareixen;

f) intencionalitat de l'autor, identificar periodisme, propaganda, manipulació, etc.;

g) descriptors per a la classificació i utilització de les imatges, a partir de conceptes històrics;

h) descriptors per a la classificació i utilització de les imatges, a partir d'elements curriculars, com el cicle, temes o activitats.

La fitxa actual és la que presentem a la figura 1.

Analitzades les fotografies i després del treball individual a l'ordinador amb el programa de tractament d'imatges, la visita i el treball al MHC permet conèixer i valorar les possibilitats didàctiques de les fonts històriques. Al mateix museu es presenten les fotografies aportades per l'alumnat, i per grups es comenten en funció dels temes, com la fabricació artesanal o industrial, les formes agrícoles, els mitjans de comunicació, la milícia, l'educació, les festes... Aquests aspectes es comparen amb la informació del museu i s'identifiquen les relacions, les contradiccions o la complementarietat de les fonts. Posteriorment es realitza una proposta de seqüència didàctica per a l'ensenyament de la història a l'escola primària.

El treball al LDCS i al MHC té com a finalitat també la comprensió de la necessitat de conservar el patrimoni històric i fotogràfic, i les fotografies familiars són les primeres que formen part d'aquest patrimoni. L'aprenentatge d'aquest valor de conservació i de l'actitud d'actuar en conseqüència dóna pas a un model de professorat i d'ensenyament de la història que defensem.

És necessari remarcar el descobriment que per a una gran part del nostre alumnat representa la recerca de documents i fotografies familiars. És una trobada amb el seu passat, que adquireix forma i fins $i$ tot rostre a les fotografies. Per un moment, alguns dels passatges històrics repassats a les classes recuperen sentit. L'alumnat pren consciència de la seva pertinença a un passat i a una història. De fet, la fotografia com a instant del passat és un document històric que ens mostra com eren, com vestien, com viatjaven o com es divertien les persones. La fotografia ens permet passar del temps de la memòria fins al temps abstracte de la història (Sega, 1986), del temps de la història familiar al temps de la història col·lectiva.

$\mathrm{Si}$ a les escoles se creen laboratoris d'imatges i es treballen les fotografies familiars, si es componen arxius i es realitzen exposicions amb els materials de l'alumnat i de les seves famílies, llavors ens trobarem davant de classes d'història on la reconstrucció del coneixement social pot ser possible: no sols reproduirem continguts, sinó que reinterpretarem el passat i el present, amb la qual cosa podríem arribar a imaginar el futur com un instrument per a la intervenció social. Si a les escoles $\mathrm{i}$ als instituts les fotografies formen part del currículum històric, llavors l'alumnat comprendrà que la història es teixeix amb una gran diversitat de retalls de petits passats.

\section{Referències bibliogràfiques}

ARQUÉ, M., GÓMEZ, P., TRIBÓ, G. Didàctica de la história amb fonts primàries. A TRIBÓ, G. (Coord.). Didàctica amb fonts d'arxius. Ed. ICE-UB. Barcelona. 2002.

BURKE, P. Visto y no visto. El uso de la imagen como documento histórico. Ed. Crítica. Barcelona. 2001.

CORRIGAN, E.M. Battling on: family history in the primary classroom. «Teaching History», 81 (1995). The Historical Association. Londres.

DEFORGE, Y. Las imágenes didácticas en las obras escolares. A COSTA, J. i MOLES, A. Imagen Didáctica. Ed. CEAC. Barcelona. 1992.

ELORZA, A. Imagen, religión y poder. A BARROS, C. (ed.). Actas del II Congreso Internacional Historia a debate, vol. II. Retorno al sujeto. La Coruña. 2000.

GASKELL, I. Historia de las imágenes. A BURKE, P. Formas de hacer Historia. Ed. Alianza Universidad. Madrid. 1994.

GAVALDÀ, A. i SANTISTEBAN, A. El laboratorio de didáctica de las ciencias sociales. A ESTEPA, J., DE LA CALLE, M., SÁNCHEZ AGUSTÍ, M. Nuevos horizontes en la formación del profesorado. Ed. ESLA. Madrid. 2002.

MORENO, M. Las imágenes de la persuasión. Materiales gráficos para la enseñanza de la Historia Contemporánea. Ed. Universidad de Alicante. Alicante. 2000.

NAVARRO, N. La utilització pedagógica de les imatges d'arxiu. A TRIBÓ, G. (Coord.). Didàctica amb fonts d'arxius. Ed. ICE UB. Barcelona. 2002.

RIEGO, B. La imagen fotográfica como un mapa de significados: el caso del estudio fotográfico, un espacio para la representación social. A III Jornades Antoni Varés. La imatge i la recerca historica. Girona. 1994.

SEGA, T. Lo specchio dotato di memoria: la fotografia. A FALTERI, P.; LAZARIN, G. Tempo. Memoria. Identita. Orientamenti per la formazione storica di base. Ed. La Nuova Italia. Firenze. 1986.

VALLS, R. Las imágenes en los manuales escolares de Historia, cillustraciones o documentos. «lber», 4 (1995). Barcelona

VICENTE, C. Els arxius d'imatges a Catalunya. «L'Avenç. Plecs d'Història Local de l'Avenç», 23 (1989). Barcelona. 